\title{
Decision support system for selecting tourist attractions using fuzzy analytic hierarchy process
}

\author{
Christa Bire $^{1}$, Daniel Kasse ${ }^{2}$, Rio Bire ${ }^{3}$ \\ ${ }^{1,2}$ Department of Electronic Engineering, State Polytechnic of Kupang, Indonesia \\ ${ }^{3}$ Department of Tourism, State Polytechnic of Kupang, Indonesia
}

\section{Article Info \\ Article history: \\ Received Dec 28, 2020 \\ Revised Mar 2, 2021 \\ Accepted Apr 12, 2021}

\section{Keywords:}

Decision support system Fuzzy analytic hierarchy process

Tourist attraction

\begin{abstract}
The selection of tourist attractions is a multi-criteria decision making problem, which requires time and careful consideration to make the right decision. The proper destination selection based on human needs in a particular moment affects satisfaction in traveling. This research aims to create a decision support system for selecting tourist attractions (a case study in Kupang City) using fuzzy analytic hierarchy process method. Users can input the priority scale of 9 human need attributes and then be directed to the system's recommendations of tourist attractions. This paper also compares fuzzy analytic hierarchy process method with the original analytic hierarchy process calculations. The result shows that both methods can be a solution for multicriteria decision making, but the fuzzy analytic hierarchy process method performs a more optimal solution for cases with uncertainty in comparisons between elements.
\end{abstract}

This is an open access article under the CC BY-SA license.

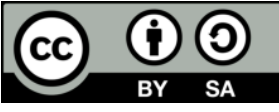

\section{Corresponding Author:}

Christa Bire

Department of Electronic Engineering

State Polytechnic of Kupang

Adi Sucipto Road, Penfui, Kupang, Nusa Tenggara Timur 85148, Indonesia

Email: christabire@pnk.ac.id

\section{INTRODUCTION}

Travel refers to the activity of travelers. Travelers are people who move between different geographic locations for any purpose and any duration [1]. Nowadays, traveling has become a priority among society, with many factors that make traveling a lifestyle. Indonesia is an island nation with many attractive tourist objects to visit. The number of international tourist visits to Indonesia shows a significant increase of 4.59 million from 2016 to 2019 [2]. The province of East Nusa Tenggara (NTT) lies in the southeastern part of Indonesia. In 2017 and 2018, NTT experienced a drastic increase in foreign and local tourist visits, reaching 1.1 million in 2017 and 1.2 million in 2018 [3].

Kupang is the capital city of NTT Province with a coastline stretching from East Kupang to West Kupang, making the city especially attractive to its nature tourism. Besides nature tourism, Kupang also has artificial tourist attractions and culinary tourism that are the uniqueness of NTT Province's capital. Various media present information about tourist attractions in Kupang, such as books, brochures, magazines, newspapers, and online media. However, it does not provide recommendations on which tourist attraction to be visited, based on traveling motivations at a particular time. Choosing a tourist attraction is a multi-criteria decision-making (MCDM) problem, which requires time and careful consideration to make the right decision. One of the various techniques to resolve the MCDM problem is the fuzzy analytic hierarchy process (FAHP) method. 
FAHP method has been widely studied and applied in various areas of life. Ayhan et al. [4] applied FAHP for supplier selection problem, Kabir et al. [5] classified inventory of multiple criteria using FAHP, Putra et al. [6] determined the quality of gemstones, and Qiaoxiu et al. [7] applied FAHP in safety evaluation of coal mines. Radionovs et al. [8] applied the FAHP method in environmental risk assessment, Essaid et al. [9] applied FAHP in educational and vocational guidance. In the tourism industry, several kinds of research had implemented FAHP method to evaluate the factors of choosing a tourist destination. Ali et al. [10] rated and ranked criteria for selecting islands in Terengganu, Malaysia. Do et al. [11] applied the FAHP method to identify the key factors that affect tourism performance in Vietnam.

Information systems, which have penetrated almost all areas of life, play a vital role in the tourism sector. A decision support system (DSS) is a computer-based information system that supports decisionmaking. A good DSS requires completeness, accuracy, punctuality, clarity, and flexibility [12]. The FAHP method had been applied to tourism decision support systems to recommend tourist destinations. Istianto et al. [13] designed a DSS of beach tourism objects in Gunungkidul, Yogyakarta, with eight assessment criteria (distance, price, safety, population, cleanliness, uniqueness, terrain, and facilities). Overbeek et al. [14] built a recommendation system for choosing tourist destinations in Kupang City using the Weighted Product method with three assessment criteria (price, facilities, and reviews of tourists).

This research aims to create a DSS for selecting tourist attractions using FAHP method to help tourists plan their tours effectively (a case study in Kupang City). The assessment process does not just consider external factors, such as price, facilities, safety, or tourist attraction quality. Unlike previous studies, this research includes internal tourist factors in choosing tourist destinations, namely the need for selfactualization, relaxation, meeting people, and adventure-seeking. The output of this DSS is a recommendation of five tourist attractions in Kupang with the highest weights. This paper also compares FAHP method with the original analytic hierarchy process (AHP) calculations.

\section{RESEARCH METHOD}

\subsection{Flowchart of the decision support system for selecting tourist attractions}

This DSS is built with bootstrap framework, PHP, Javascript, dan XAMPP. Figure 1 shows the flowchart of the built DSS.

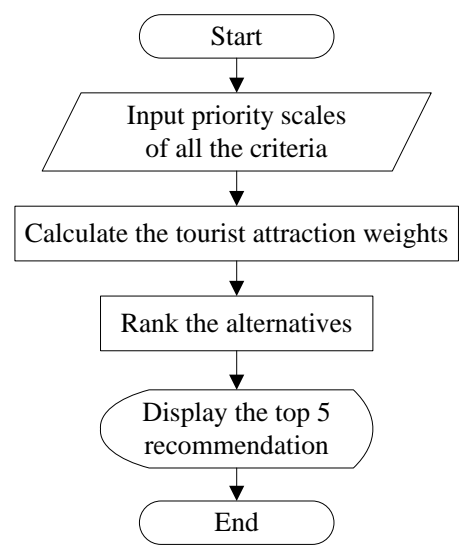

Figure 1. DSS flowchart

\subsection{FAHP}

FAHP method is a development of the AHP method. Crisp numbers of the AHP scale are considered less capable of handling uncertainty, so the original AHP scale must be approached by fuzzy logic [15], [16]. The development of FAHP was to overcome the uncertainty and subjectivity of input data more effectively than conventional MCDM techniques [17], [18]. FAHP method is the merger of the AHP method and fuzzy logic developed by Zadeh [19], where fuzzy numbers apply in determining the degree of importance in a comparison matrix. There are types of fuzzy number models, including triangular fuzzy number, trapezoidal fuzzy number, and gaussian fuzzy number. triangular fuzzy number (TFN) is the most common form of a fuzzy number among other fuzzy numbers [10] and is more convenient to use in applications because of its computational simplicity [20], [21]. Three membership functions of the TFN scale, as shown in Figure 2, are 
1 (lowest value), $\mathrm{m}$ (middle value), and u (highest value). The procedure of FAHP method consists of 6 steps shown in the following block diagram in Figure 3.

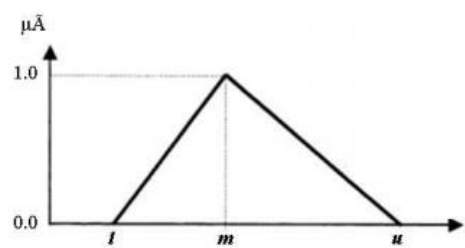

Figure 2. The scale of TFN [22]

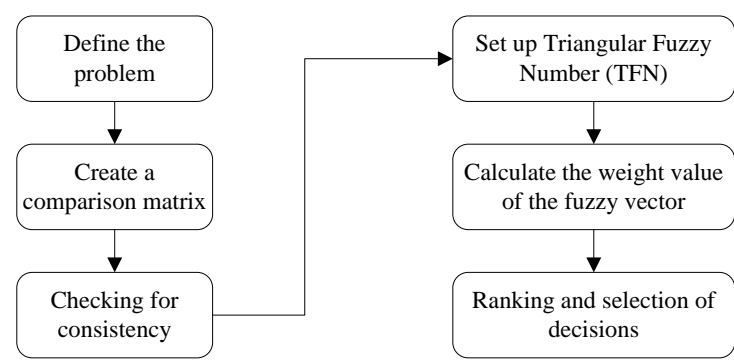

Figure 3. Six steps phase process of FAHP [6]

a. Define the problem

The complex multi-criteria problem is transformed to a hierarchical model so that the problem appears to be more structured and systematic as shown in Figure 4. The top-level in the hierarchy is the main objective of the problem, then broken down to the next level of 9 criteria, to the lowest level of alternatives, which are 14 tourist attractions in Kupang. The assessment criteria used in this research is based on human needs, adopted from the study of preference analysis for tourist choice of destination by Hsu et al. [23] with some alteration adjusted to the characteristics of tourist attractions in Kupang, considering internal factors (criteria 1-5) and external factors (criteria 6-9).

b. Create a comparison matrix

The pairwise comparison matrix is created with provisions of the AHP scale by Thomas Saaty [24] which is shown in Table 1.

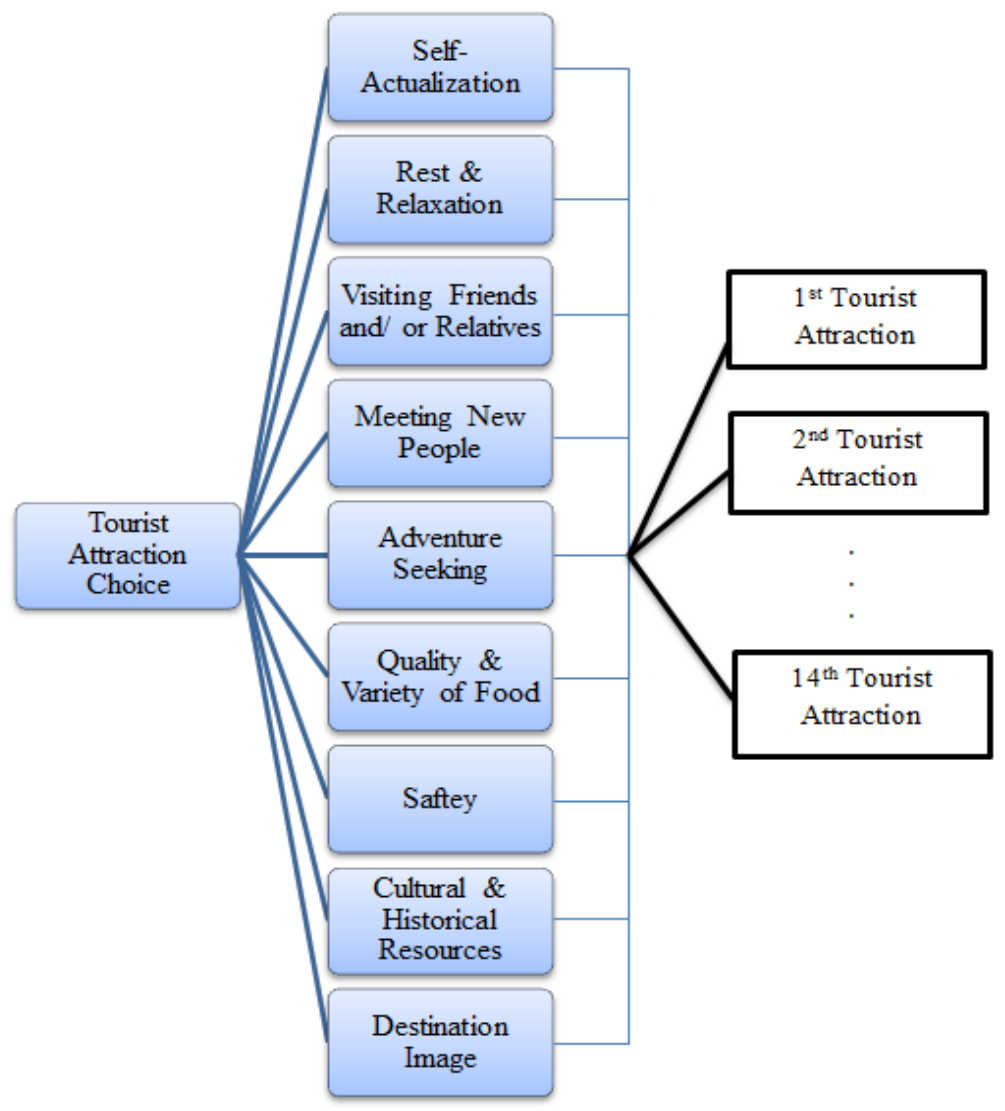

Figure 4. The hierarchy of selecting tourist attractions 
The fourteen tourist attractions in Kupang City are written with abbreviations to shorten the names of the tourist attractions, namely Lasiana Beach (LB), Crystal Cave (CC), Monkey Cave (MC), Color Beach (CB), Namosain Beach (NB), Batu Nona Beach. (BB), Koepan Beach (KB), Kupang Waterpark (KW), Subasuka Waterpark (SW), Nostalgia Park (NP), Tomb of Taebenu Kings (TT), Kerkof (KR), The Old Church of Kupang City (OC), and NTT Regional Museum (RM).

Table 1. The scale of AHP

\begin{tabular}{cl}
\hline Intensity of Importance & \multicolumn{1}{c}{ Definition } \\
\hline 1 & Equal importance \\
2 & Weak or Slight \\
3 & Moderate importance \\
4 & Moderate plus \\
5 & Strong importance \\
6 & Strong plus \\
7 & Very Strong or Demonstrated Importance \\
8 & Very, very strong \\
9 & Extreme importance \\
\hline
\end{tabular}

c. Check for consistency

The matrix consistency check is calculated by the following formula:

$$
C R=C I / R I
$$

$\mathrm{CI}$ is the consistency index, and RI is the random generator value shown in Table 2. The following formula is for calculating $\mathrm{CI}$ :

$$
C I=(\lambda \max -n) /(n-1)
$$

\begin{tabular}{|c|c|c|c|c|c|c|c|c|c|c|c|c|c|c|c|}
\hline \multicolumn{16}{|c|}{ Random Index (RI) } \\
\hline $\mathrm{N}$ & 1 & 2 & 3 & 4 & 5 & 6 & 7 & 8 & 9 & 10 & 11 & 12 & 13 & 14 & 15 \\
\hline RI & 0 & 0 & 0.58 & 0.90 & 1.12 & 1.24 & 1.32 & 1.41 & 1.45 & 1.49 & 1.51 & 1.48 & 1.56 & 1.57 & 1.58 \\
\hline
\end{tabular}

Table 2. Random index [24]-[25]

$\lambda \max$ is the maximum eigenvalue from the $n x n$ matrix. The steps to obtain $\lambda \max$ are matrix normalization, which means dividing the element's value by the number of columns; calculating the weight vector (W), which is the average value of each matrix row; and multiplying the pairwise comparison matrix with the weight vector, generating an eigenvalue $(\mathrm{EV})$. Then $\lambda \max$ can be calculated with the following formula:

$$
\lambda \max =1 / n x\left(\sum E V / W\right)
$$

d. Set up triangular fuzzy number (TFN)

After obtaining a consistent matrix, the AHP pairwise comparison scale is then converted into triangular fuzzy numbers. Table 3 shows the linguistic terms and the corresponding TFNs.

Table 3. Linguistic terms and the corresponding TFNs [3]

\begin{tabular}{clc}
\hline Saaty Scale & Definition & Fuzzy Triangular Scale \\
\hline 1 & Equally important & $(1,1,1)$ \\
3 & Weekly important & $(2,3,4)$ \\
5 & Fairly important & $(4,5,6)$ \\
7 & Strongly important & $(6,7,8)$ \\
9 & Absolutely important & $(9,9,9)$ \\
2 & & $(1,2,3)$ \\
4 & The intermittent & $(3,4,5)$ \\
6 & values between two & $(5,6,7)$ \\
8 & adjective scales & $(7,8,9)$ \\
\hline
\end{tabular}

e. Calculate the weight value of the fuzzy vector

Extent analysis is a method proposed by Chang to obtain the synthesis value of the fuzzy pairwise comparison. The extent analysis procedure is as follows [26]-[27]:

- Calculate the fuzzy synthetic extent value. The fuzzy synthetic extent value for i-objects is defined as: 


$$
S_{i}=\sum_{j=1}^{m} M_{g i}^{j} x\left[\sum_{i=1}^{n} \sum_{j=1}^{m} M_{g i}^{j}\right]^{-1}
$$

where $\mathrm{M}$ represents the TFN, $\mathrm{m}$ as the number of elements, $j$ as columns, $i$ as rows, and $g$ as the parameters $(l, m, u)$.

- $\quad$ Possibility level comparison between fuzzy numbers

For two TFNs, $M_{1=}\left(l_{1}, m_{1}, u_{1}\right)$ dan $M_{2}=\left(l_{2}, m_{2}, u_{2}\right)$ with probability level of $M_{2} \geq M_{1}$ is defined as:

$$
V\left(M_{2} \geq M_{1}\right)=\sup \left[\min \left(\mu_{M 1}(x), \mu_{M 2}(y)\right)\right]
$$

The probability level for convex fuzzy numbers is obtained with the following equation:

$$
V\left(M_{2} \geq M_{1}\right)=\left\{\begin{array}{c}
1, \text { if } m_{2} \geq m_{1} \\
0, \text { if } l_{1} \geq u_{2} \\
\frac{l_{1}-u_{2}}{\left(m_{2}-u_{2}\right)-\left(m_{1}-l_{1}\right)}, \text { other }
\end{array}\right.
$$

- $\quad$ The possibility level for a convex fuzzy number to be greater than k convex fuzzy numbers M i ( $\mathrm{i}=1,2$. $\ldots . . \mathrm{k})$ can be defined by;

$$
\begin{aligned}
& V\left(M \geq M_{1}, M_{2}, \ldots, M_{k}\right)= \\
& V\left[\left(M \geq M_{1}\right) \text { and }\left(M \geq M_{2}\right) \text { and } \ldots \text { and }\left(M \geq M_{k}\right)\right]= \\
& \min V\left(M \geq M_{i}\right)
\end{aligned}
$$

where $\mathrm{i}=1,2,3 \ldots \mathrm{k}$.

Assume that:

$$
d\left(A_{i}\right)=\min V\left(S_{i} \geq S_{k}\right)
$$

where $\mathrm{k}=1,2, \ldots, \mathrm{n} ; \mathrm{k} \neq \mathrm{i}$, then the weight vector is given by:

$$
W^{\prime}=\left(d^{\prime}\left(A_{1}\right), d^{\prime}\left(A_{2}\right), \ldots \ldots \ldots, d^{\prime}\left(A_{n}\right)\right)^{T}
$$

where $A_{i}(i=1,2, \ldots n)$ are $n$ elements.

- Normalization

The normalized weight vector is obtained by the following equation:

$$
W=\left(d\left(A_{1}\right), d\left(A_{2}\right), \ldots \ldots, d\left(A_{n}\right)\right)^{T}
$$

where $\mathrm{W}$ is a non-fuzzy number.

\section{RESULTS AND DISCUSSION}

Starting from the lowest level of the hierarchy, the pairwise comparison matrix of the alternatives on all criteria is created from real tourist assessments via questionnaires. The pairwise comparison for the first criteria (K1) is shown in Table 4. After determining the pairwise comparison matrix for each of the criteria, the next step is to normalize the matrix (results are shown in Table 5), then calculate the $\lambda$ max. The calculation result for the alternative's pairwise comparison matrix for $\mathrm{K} 1$ is shown below:

$\mathrm{W}=(0.078,0.078,0.044,0.078,0.078,0.078,0.078,0.078,0.078,0.078,0.013,0.013,0.144,0.078)$.

$\mathrm{EV}=(1.105,0.618,1.105,1.105,1.105,1.105,1.105,1.105,1.105,1.105,0.187,0.187,2.033,1.105)$.

$\lambda \max =\frac{1}{14} x\left(\frac{1.105}{0.078}+\frac{0.618}{0.078}+\frac{1.105}{0.078}+\frac{1.105}{0.078}+\frac{1.105}{0.078}+\frac{1.105}{0.078}+\frac{1.105}{0.078}+\frac{1.105}{0.078}+\frac{1.105}{0.078}+\frac{1.105}{0.078}+\frac{0.187}{0.013}+\frac{0.187}{0.013}+\frac{2.033}{0.144}+\frac{1.105}{0.078}=\right.$ 14.068)

Based on the $\lambda$ max, consistency ratio is obtained as follows:

$$
C I=\frac{14.068-14}{14-1}=0.005 \quad C R=\frac{0.005}{1.57}=0.003
$$

The matrix is consistent because the $\mathrm{CR}$ value is $<0.1$ and thereafter can be altered to triangular fuzzy numbers by the conditions in Table 3 . The alternative's fuzzy pairwise comparison for K1 is shown in Table 6. 
Table 4. The alternative's pairwise comparison matrix for K1

\begin{tabular}{ccccccccccccccc}
\hline & LB & CC & MC & CB & NB & BB & KB & KW & SW & NP & TT & KR & OC & RM \\
\hline LB & 1 & 1 & 2 & 1 & 1 & 1 & 1 & 1 & 1 & 1 & 6 & 6 & $1 / 2$ & 1 \\
CC & 1 & 1 & 2 & 1 & 1 & 1 & 1 & 1 & 1 & 1 & 6 & 6 & $1 / 2$ & 1 \\
MC & $1 / 2$ & $1 / 2$ & 1 & $1 / 2$ & $1 / 2$ & $1 / 2$ & $1 / 2$ & $1 / 2$ & $1 / 2$ & $1 / 2$ & 5 & 5 & $1 / 3$ & $1 / 2$ \\
CB & 1 & 1 & 2 & 1 & 1 & 1 & 1 & 1 & 1 & 1 & 6 & 6 & $1 / 2$ & 1 \\
NB & 1 & 1 & 2 & 1 & 1 & 1 & 1 & 1 & 1 & 1 & 6 & 6 & $1 / 2$ & 1 \\
BB & 1 & 1 & 2 & 1 & 1 & 1 & 1 & 1 & 1 & 1 & 6 & 6 & $1 / 2$ & 1 \\
KB & 1 & 1 & 2 & 1 & 1 & 1 & 1 & 1 & 1 & 1 & 6 & 6 & $1 / 2$ & 1 \\
KW & 1 & 1 & 2 & 1 & 1 & 1 & 1 & 1 & 1 & 1 & 6 & 6 & $1 / 2$ & 1 \\
SW & 1 & 1 & 2 & 1 & 1 & 1 & 1 & 1 & 1 & 1 & 6 & 6 & $1 / 2$ & 1 \\
NP & 1 & 1 & 2 & 1 & 1 & 1 & 1 & 1 & 1 & 1 & 6 & 6 & $1 / 2$ & 1 \\
TT & $1 / 6$ & $1 / 6$ & $1 / 5$ & $1 / 6$ & $1 / 6$ & $1 / 6$ & $1 / 6$ & $1 / 6$ & $1 / 6$ & $1 / 6$ & 1 & 1 & $1 / 7$ & $1 / 6$ \\
KR & $1 / 6$ & $1 / 6$ & $1 / 5$ & $1 / 6$ & $1 / 6$ & $1 / 6$ & $1 / 6$ & $1 / 6$ & $1 / 6$ & $1 / 6$ & 1 & 1 & $1 / 7$ & $1 / 6$ \\
$\mathrm{OC}$ & 2 & 2 & 3 & 2 & 2 & 2 & 2 & 2 & 2 & 2 & 7 & 7 & 1 & 2 \\
$\mathrm{RM}$ & 1 & 1 & 2 & 1 & 1 & 1 & 1 & 1 & 1 & 1 & 6 & 6 & $1 / 2$ & 1 \\
\hline
\end{tabular}

Table 5. Normalized alternative matrix for K1

\begin{tabular}{cccccccccccccccc}
\hline & LB & CC & MC & CB & NB & BB & KB & KW & SW & NP & TT & KR & OC & RM \\
\hline LB & 0.078 & 0.078 & 0.082 & 0.078 & 0.078 & 0.078 & 0.078 & 0.078 & 0.078 & 0.078 & 0.081 & 0.081 & 0.076 & 0.078 \\
CC & 0.078 & 0.078 & 0.082 & 0.078 & 0.078 & 0.078 & 0.078 & 0.078 & 0.078 & 0.078 & 0.081 & 0.081 & 0.076 & 0.078 \\
MC & 0.039 & 0.039 & 0.041 & 0.039 & 0.039 & 0.039 & 0.039 & 0.039 & 0.039 & 0.039 & 0.068 & 0.068 & 0.050 & 0.039 \\
CB & 0.078 & 0.078 & 0.082 & 0.078 & 0.078 & 0.078 & 0.078 & 0.078 & 0.078 & 0.078 & 0.081 & 0.081 & 0.076 & 0.078 \\
NB & 0.078 & 0.078 & 0.082 & 0.078 & 0.078 & 0.078 & 0.078 & 0.078 & 0.078 & 0.078 & 0.081 & 0.081 & 0.076 & 0.078 \\
BB & 0.078 & 0.078 & 0.082 & 0.078 & 0.078 & 0.078 & 0.078 & 0.078 & 0.078 & 0.078 & 0.081 & 0.081 & 0.076 & 0.078 \\
KB & 0.078 & 0.078 & 0.082 & 0.078 & 0.078 & 0.078 & 0.078 & 0.078 & 0.078 & 0.078 & 0.081 & 0.081 & 0.076 & 0.078 \\
KW & 0.078 & 0.078 & 0.082 & 0.078 & 0.078 & 0.078 & 0.078 & 0.078 & 0.078 & 0.078 & 0.081 & 0.081 & 0.076 & 0.078 \\
SW & 0.078 & 0.078 & 0.082 & 0.078 & 0.078 & 0.078 & 0.078 & 0.078 & 0.078 & 0.078 & 0.081 & 0.081 & 0.076 & 0.078 \\
NP & 0.078 & 0.078 & 0.082 & 0.078 & 0.078 & 0.078 & 0.078 & 0.078 & 0.078 & 0.078 & 0.081 & 0.081 & 0.076 & 0.078 \\
TT & 0.013 & 0.013 & 0.008 & 0.013 & 0.013 & 0.013 & 0.013 & 0.013 & 0.013 & 0.013 & 0.014 & 0.014 & 0.022 & 0.013 \\
KR & 0.013 & 0.013 & 0.008 & 0.013 & 0.013 & 0.013 & 0.013 & 0.013 & 0.013 & 0.013 & 0.014 & 0.014 & 0.022 & 0.013 \\
OC & 0.156 & 0.156 & 0.123 & 0.156 & 0.156 & 0.156 & 0.156 & 0.156 & 0.156 & 0.156 & 0.095 & 0.095 & 0.151 & 0.156 \\
RM & 0.078 & 0.078 & 0.082 & 0.078 & 0.078 & 0.078 & 0.078 & 0.078 & 0.078 & 0.078 & 0.081 & 0.081 & 0.076 & 0.078 \\
\hline
\end{tabular}

Table 6. The alternative's fuzzy pairwise comparison for K1

\begin{tabular}{cccccccccc}
\hline & LB & CC & MC & CB & NB & BB & $\ldots$ & OC & RM \\
\hline LB & $1,1,1$ & $1,1,1$ & $1,2,3$ & $1,1,1$ & $1,1,1$ & $1,1,1$ & $\ldots$ & $1 / 3,1 / 2,1$ & $1,1,1$ \\
CC & $1,1,1$ & $1,1,1$ & $1,2,3$ & $1,1,1$ & $1,1,1$ & $1,1,1$ & $\ldots$ & $1 / 3,1 / 2,1$ & $1,1,1$ \\
MC & $1 / 3,1 / 2,1$ & $1 / 3,1 / 2,1$ & $1,1,1$ & $1 / 3,1 / 2,1$ & $1 / 3,1 / 2,1$ & $1 / 3,1 / 2,1$ & $\ldots$ & $1 / 4,1 / 3,1 / 2$ & $1 / 3,1 / 2,1$ \\
CB & $1,1,1$ & $1,1,1$ & $1,2,3$ & $1,1,1$ & $1,1,1$ & $1,1,1$ & $\ldots$ & $1 / 3,1 / 2,1$ & $1,1,1$ \\
NB & $1,1,1$ & $1,1,1$ & $1,2,3$ & $1,1,1$ & $1,1,1$ & $1,1,1$ & $\ldots$ & $1 / 3,1 / 2,1$ & $1,1,1$ \\
BB & $1,1,1$ & $1,1,1$ & $1,2,3$ & $1,1,1$ & $1,1,1$ & $1,1,1$ & $\ldots$ & $1 / 3,1 / 2,1$ & $1,1,1$ \\
. &. &. &. &. &. &. & $\ldots$ &. &. \\
. &. &. &. &. &. &. & $\ldots$ &. &. \\
. &. &. &. &. &. &. & $\ldots$ &. &. \\
RC & $1,2,3$ & $1,2,3$ & $2,3,4$ & $1,2,3$ & $1,2,3$ & $1,2,3$ & $\ldots$ & $1,1,1$ & $1,2,3$ \\
\hline
\end{tabular}

By using (4), the calculation of the fuzzy synthetic extent value can be seen in Table 7. From (6) and (7), the fuzzy convex comparison value is obtained and shown in Table 8. Based on (9) the weight vector is obtained as $\mathrm{W}^{\prime}=(0.474,0.474,0.239,0.474,0.474,0.474,0.474,0.474,0.474,0.474,0,0,1,0.474)$. The normalized weight vector based on equation (10) is $\mathrm{W}=(0.079,0.079,0.040,0.079,0.079,0.079,0.079$, $0.079,0.079,0.079,0,0,0.167,0.079)$. The calculation generates the alternatives weights for $\mathrm{K} 1-\mathrm{K} 9$ as shown in Table 9. These weight calculation results of 14 tourist attractions for all the criteria are inserted into a database, which is allowed to be updated in the future whenever the evaluations for the tourist attractions changes. To obtain the final weights, the previously inserted alternative weights are then multiplied with the criteria weights obtained from the user's input via the website. Figure 5 shows a simulation of users' input of the 9 criteria priority scale, while the recommendation result is shown in Figure 6. By clicking the submit button as shown in Figure 4, the DSS will process the input values by converting the numbers to a comparison matrix of fuzzy numbers, calculate the final weights, and rank the top five tourist attractions.

In the first scenario, the user is very concerned with K1 (self-actualization), K2 (rest \& relaxation), K6 (quality and variety of food), and K7 (safety). Meanwhile, K3 (visiting friends/relatives), K4 (meeting new people), and K8 (cultural \& historical resources) have the lowest priority value, whereas K5 (adventureseeking) and K9 (destination image) have middle priority. In the second scenario, K2 (rest \& relaxation), K3 (visiting friends/relatives), K8 (cultural \& historical resources), K6 (quality and variety of food), and K7 (safety) have the highest priority value. Meanwhile, K4 (meeting new people) and K5 (adventure-seeking) have the lowest priority value, while K1 (self-actualization) and K9 (destination image) have the middle 
priority value. In the third scenario, the user is more concerned with the external factors, which are K6 (quality and variety of food), K7 (safety), K8 (cultural \& historical resources), and K9 (destination image).

Table 7. Fuzzy synthetic extent value for K1

\begin{tabular}{cccc}
\hline Tourist Attraction & \multicolumn{3}{c}{ Fuzzy synthetic extent value } \\
\hline LB & 0.059 & 0.080 & 0.108 \\
CC & 0.059 & 0.080 & 0.108 \\
MC & 0.035 & 0.053 & 0.091 \\
CB & 0.059 & 0.080 & 0.108 \\
NB & 0.059 & 0.080 & 0.108 \\
BB & 0.059 & 0.080 & 0.108 \\
KB & 0.059 & 0.080 & 0.108 \\
KW & 0.059 & 0.080 & 0.108 \\
SW & 0.059 & 0.080 & 0.108 \\
NP & 0.059 & 0.080 & 0.108 \\
TT & 0.010 & 0.013 & 0.017 \\
KR & 0.010 & 0.013 & 0.017 \\
OC & 0.069 & 0.124 & 0.197 \\
RM & 0.059 & 0.080 & 0.108 \\
\hline
\end{tabular}

Table 8. Fuzzy convex comparison value for K1

\begin{tabular}{lllllll}
\hline & LB & CC & MC & $\ldots$ & OC & RM \\
\hline LB & & 1.000 & 0.548 & $\ldots$ & 1.000 & 1.000 \\
CC & 1.000 & & 0.548 & $\ldots$ & 1.000 & 1.000 \\
MC & 1.000 & 1.000 & & $\ldots$ & 1.000 & 1.000 \\
. &. &. &. & $\ldots$ &. &. \\
. &. &. &. & $\ldots$ &. &. \\
. &. &. &. & $\ldots$ &. &. \\
OC & 0.474 & 0.474 & 0.239 & $\ldots$ & & 0.474 \\
RM & 1.000 & 1.000 & 0.548 & $\ldots$ & 1.000 & \\
\hline MIN & 0.474 & 0.474 & 0.239 & $\ldots$ & 1.000 & 0.474 \\
\hline
\end{tabular}

Table 9. Alternative weights

\begin{tabular}{|c|c|c|c|c|c|c|c|c|c|c|c|c|c|c|}
\hline \multirow{2}{*}{ Criteria } & \multicolumn{14}{|c|}{ Tourist Attraction Weights } \\
\hline & LB & $\mathrm{CC}$ & $\mathrm{MC}$ & $\mathrm{CB}$ & NB & $\mathrm{BB}$ & KB & KW & SW & NP & $\mathrm{TT}$ & KR & $\mathrm{OC}$ & $\mathrm{RM}$ \\
\hline $\mathrm{K} 2$ & 0.111 & 0.056 & 0.056 & 0.111 & 0.111 & 0.111 & 0.111 & 0.111 & 0.111 & 0.111 & 0.000 & 0.000 & 0.000 & 0.000 \\
\hline K4 & 0.077 & 0.077 & 0.059 & 0.110 & 0.077 & 0.110 & 0.110 & 0.110 & 0.078 & 0.110 & 0.000 & 0.000 & 0.000 & 0.078 \\
\hline K5 & 0.000 & 0.275 & 0.186 & 0.000 & 0.000 & 0.000 & 0.000 & 0.234 & 0.230 & 0.000 & 0.000 & 0.000 & 0.000 & 0.075 \\
\hline K6 & 0.112 & 0.000 & 0.000 & 0.153 & 0.000 & 0.121 & 0.153 & 0.153 & 0.153 & 0.153 & 0.000 & 0.000 & 0.000 & 0.000 \\
\hline K9 & 0.065 & 0.120 & 0.000 & 0.120 & 0.065 & 0.065 & 0.065 & 0.065 & 0.065 & 0.065 & 0.063 & 0.000 & 0.120 & 0.120 \\
\hline
\end{tabular}

$$
\text { Kupang City Tourism }
$$

\begin{tabular}{|c|c|c|}
\hline No & Criteria & Priority Scale \\
\hline 1 & Self-actualization & $\bigcirc 1 \bigcirc 2 \bigcirc 3 \bigcirc 4 \bigcirc 5$ \\
\hline 2 & Rest and relaxation & $\bigcirc 1 \bigcirc 2 \bigcirc 3 \bigcirc 4 \bigcirc 5$ \\
\hline 3 & Visiting friends and/ or relatives & $01 \bigcirc 2 \bigcirc 3 \bigcirc 4 \bigcirc 5$ \\
\hline 4 & Meeting new people & $\bigcirc 1 \bigcirc 2 \bigcirc 3 \bigcirc 4 \bigcirc 5$ \\
\hline 5 & Adventure seeking & $\bigcirc 1 \bigcirc 2 \bigcirc 3 \bigcirc 4 \bigcirc 5$ \\
\hline 6 & Quality and variety of food & $\bigcirc 1 \bigcirc 2 \bigcirc 3 \bigcirc 4 \bigcirc 5$ \\
\hline 7 & Saftey & $\bigcirc_{1} \bigcirc_{2} \bigcirc_{3} \bigcirc 4 \bigcirc 5$ \\
\hline 8 & Cultural and historical resources & $0_{1} \bigcirc 2 \bigcirc_{3} \bigcirc 4 \bigcirc 5$ \\
\hline 9 & Destination image & $\mathrm{O}_{1} \bigcirc_{2} \mathrm{O}_{3} \bigcirc_{4} \bigcirc_{5}$ \\
\hline
\end{tabular}

Figure 5. Priority scale input simulation

Table 10 shows three different scenarios of the criteria priority scale input. Recommendation result; Tables 11-13 shows the comparison results of manual FAHP calculation, the DSS' FAHP calculation, and the AHP calculation for all of the scenarios. Table 11 points out the recommendation sequence of the two methods are different. Moreover, there are some equal weights of tourist attractions using the FAHP method, which has a distant weight difference with the AHP method (see KB and NP, as well as LB and BB). Similar to Table 11, Table 12 also shows some equal weights of tourist attractions using the FAHP method, which 
has a distant weight difference with the AHP method (see $\mathrm{KB}$ and $\mathrm{KW}$, as well as LB and $\mathrm{BB}$ ). Table 13 shows that both methods have nearly the same results because two criteria have a small degree of uncertainty, which are K6 (quality \& variety of food) and K8 (culture \& historical resources). K6 could only be owned by tourist attractions that provide food, while $\mathrm{K} 8$ cannot be owned by tourist attractions that do not have cultural and historical resources.

Table 10. Priority scale input scenarios

\begin{tabular}{cccc}
\multicolumn{4}{c}{ scenarios } \\
\hline \multirow{3}{*}{ Criteria } & \multicolumn{3}{c}{ Priority Scale } \\
\cline { 2 - 4 } & Scenario & Scenario & Scenario \\
& 1 & 2 & 3 \\
\hline K1 & 5 & 3 & 2 \\
K2 & 5 & 5 & 2 \\
K3 & 1 & 5 & 2 \\
K4 & 1 & 1 & 2 \\
K5 & 3 & 1 & 1 \\
K6 & 5 & 5 & 5 \\
K7 & 5 & 5 & 5 \\
K8 & 1 & 1 & 5 \\
K9 & 4 & 3 & 5 \\
\hline
\end{tabular}

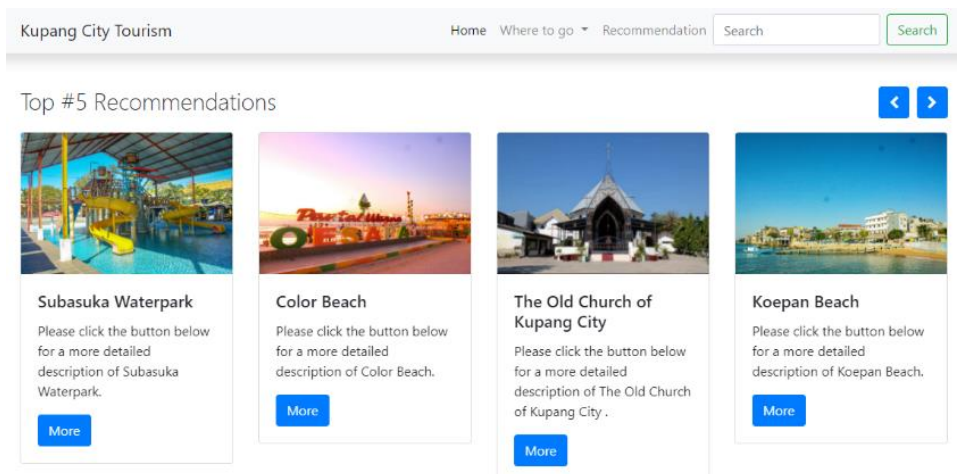

Figure 6. Recommendation results

Table 11. Result of scenario 1

\begin{tabular}{ccccccc}
\hline No & Tourist Attraction & AHP method & FAHP method & DSS with FAHP & Rank with AHP & Rank with FAHP \\
\hline 1 & LB & 0.077 & 0.079 & 0.079 & 10 & 7 \\
2 & CC & 0.084 & 0.040 & 0.040 & 9 & 11 \\
3 & MC & 0.047 & 0.022 & 0.022 & 13 & 12 \\
4 & CB & 0.103 & 0.117 & 0.117 & 3 & 1 \\
5 & NB & 0.063 & 0.055 & 0.055 & 11 & 7 \\
6 & BB & 0.093 & 0.079 & 0.079 & 5 & 4 \\
7 & KB & 0.100 & 0.092 & 0.092 & 4 & 4 \\
8 & KW & 0.092 & 0.0 .92 & 0.092 & 6 & 1 \\
9 & SW & 0.115 & 0.137 & 0.137 & 1 & 13 \\
10 & NP & 0.086 & 0.092 & 0.092 & 8 & 14 \\
11 & TT & 0.060 & 0.013 & 0.013 & 12 & 3 \\
12 & KR & 0.044 & 0.003 & 0.003 & 14 & 9 \\
13 & OC & 0.113 & 0.108 & 0.108 & 2 & 7 \\
14 & RM & 0.089 & 0.071 & 0.071 & & \\
\hline
\end{tabular}

In the FAHP calculation results, there are two to three tourist attractions with the same weight. It is due to the equal ratings by tourists on the tourist attractions of more than one criterion. If the prioritized criteria have the same weight on two or three tourist attractions, then the final weight is likely to be the same, depending on the priority scale given to other criteria. The results provided by FAHP are closer to human thinking and logic because there is uncertainty in the pairwise comparison, which causes two to three tourist attractions to have no significant differences. Crsip assesments, both from comparisons between alternatives and between criteria, cause tourist attractions with a small difference, have a very much different final weight.

Table 12. Result of scenario 2

\begin{tabular}{|c|c|c|c|c|c|c|}
\hline No & Tourist Attraction & AHP method & FAHP method & DSS with FAHP & Rank with AHP & Rank with FAHP \\
\hline 1 & LB & 0.088 & 0.093 & 0.093 & 8 & 6 \\
\hline 2 & $\mathrm{CC}$ & 0.075 & 0.031 & 0.031 & 10 & 11 \\
\hline 3 & MC & 0.043 & 0.021 & 0.021 & 14 & 12 \\
\hline 4 & $\mathrm{CB}$ & 0.112 & 0.123 & 0.123 & 2 & 2 \\
\hline 5 & NB & 0.063 & 0.056 & 0.056 & 11 & 9 \\
\hline 6 & BB & 0.104 & 0.093 & 0.093 & 3 & 6 \\
\hline 7 & KB & 0.102 & 0.096 & 0.096 & 4 & 4 \\
\hline 8 & KW & 0.088 & 0.096 & 0.096 & 7 & 4 \\
\hline 9 & SW & 0.121 & 0.154 & 0.154 & 1 & 1 \\
\hline 10 & NP & 0.096 & 0.107 & 0.107 & 5 & 3 \\
\hline 11 & TT & 0.060 & 0.012 & 0.012 & 12 & 13 \\
\hline 12 & KR & 0.044 & 0.003 & 0.003 & 13 & 14 \\
\hline 13 & $\mathrm{OC}$ & 0.094 & 0.062 & 0.062 & 6 & 8 \\
\hline 14 & $\mathrm{RM}$ & 0.083 & 0.053 & 0.053 & 9 & 10 \\
\hline
\end{tabular}


Table 13. Result of scenario 3

\begin{tabular}{|c|c|c|c|c|c|c|}
\hline No & Tourist Attraction & AHP method & FAHP method & DSS with FAHP & Rank with AHP & Rank with FAHP \\
\hline 1 & LB & 0.061 & 0.046 & 0.046 & 11 & 11 \\
\hline 2 & $\mathrm{CC}$ & 0.070 & 0.075 & 0.075 & 8 & 6 \\
\hline 3 & $\mathrm{MC}$ & 0.034 & 0.008 & 0.008 & 14 & 14 \\
\hline 4 & $\mathrm{CB}$ & 0.084 & 0.098 & 0.098 & 5 & 3 \\
\hline 5 & NB & 0.045 & 0.020 & 0.020 & 13 & 13 \\
\hline 6 & $\mathrm{BB}$ & 0.077 & 0.075 & 0.075 & 6 & 7 \\
\hline 7 & KB & 0.085 & 0.088 & 0.088 & 3 & 5 \\
\hline 8 & KW & 0.070 & 0.060 & 0.060 & 9 & 9 \\
\hline 9 & SW & 0.085 & 0.090 & 0.090 & 4 & 4 \\
\hline 10 & NP & 0.071 & 0.060 & 0.060 & 7 & 9 \\
\hline 11 & TT & 0.065 & 0.062 & 0.062 & 10 & 8 \\
\hline 12 & $\mathrm{KR}$ & 0.045 & 0.035 & 0.035 & 12 & 12 \\
\hline 13 & $\mathrm{OC}$ & 0.104 & 0.152 & 0.152 & 1 & 1 \\
\hline 14 & $\mathrm{RM}$ & 0.091 & 0.134 & 0.134 & 2 & 2 \\
\hline
\end{tabular}

\section{CONCLUSION}

This DSS can help prospective tourists in selecting tourist attractions based on the motives of their trip. The performance of the DSS shows the same results as the manual FAHP calculations, meaning that the DSS can process the FAHP calculations correctly. The recommendation sequence of tourist attractions of both FAHP and AHP method is different. This difference is due to the use of TFN in pairwise comparisons between elements in the FAHP method, which is different from AHP that uses crisp numbers. Both the AHP and the FAHP method can be a solution for multi-criteria decision making, but the FAHP method performs a more optimal solution for cases that contain uncertainty in comparisons between elements. In the end, the DSS is not the final decision maker, but only providing recommendations for the DSS users. The final decisions are decided by the decision-maker, in this case, are prospective tourists who plan to visit Kupang City for a tour. The final weights also depend on the judgment/assessment given by the user.

\section{ACKNOWLEDGEMENTS}

The author wants to thank the State Polytechnic of Kupang for financial support through the ROUTINE Research program.

\section{REFERENCES}

[1] United Nations. Statistical Division," International recommendations for tourism statistics 2008. United Nations Publications; 2010.

[2] Badan Pusat Statistik, "Indonesian Statistics (in Indonesia: Statistik Indonesia)," Badan Pusat Statistik, 2019.

[3] Badan Pusat Statistik Propinsi Nusa Tenggara Timur, "East Nusa Tenggara Province in 2019 (in Indonesia: Propinsi Nusa Tenggara Timur Dalam Angka 2019),” BPS Nusa Tenggara Timur, 2019.

[4] Ayhan M. B., "A Fuzzy Ahp Approach For Supplier Selection Problem: A Case Study In A Gearmotor Company," International Journal of Managing Value and Supply Chains (IJMVSC), vol. 4, no. 3, pp. 11-23, 2013, doi: 10.5121/ijmvsc.2013.4302.

[5] Kabir G., Hasin M. A. A., "Multiple Criteria Inventory Classification Using Fuzzy Analytic Hierarchy Process," International Journal of Industrial Engineering Computations, vol. 3, no. 2, pp. 123-132, 2012, doi: 10.5267/j.ijiec.2011.09.007.

[6] Putra M. S. D., Andryana S., Fauziah, Gunaryati, A., "Fuzzy Analytical Hierarchy Process Method to Determine the Quality of Gemstones," Advances in Fuzzy Systems, vol. 2018, pp. 1-6, 2018.

[7] Qiaoxiu W., Hong W., Zuoqiu Q., "An application of nonlinear fuzzy analytic hierarchy process in safety evaluation of coal mine," Safety Science, vol. 86, no. 2016, pp. 78-87, 2016, doi: 10.1016/j.ssci.2016.02.012

[8] Radionovs A., Uzhga-Rebrov O., "Comparison of Different Fuzzy AHP Methodologies in Risk Assessment," Proceedings of the 11th International Scientific and Practical Conference, vol. 2, pp. 137-142, 2017, doi: 10.17770/etr2017vol2.2521

[9] Essaid E. L., Azmani A., El Harzli M., "Using FAHP in the Educational and Vocational Guidance," International Journal of Modern Education and Computer Science (IJMECS), vol. 10, no. 12, pp. 36-43, 2018, doi: 10.5815/ijmecs.2018.12.05.

[10] Ali N. H., Sabri I. A., Noor N. M., Ismail F., "Rating and Ranking Criteria for Selected Islands using Fuzzy Analytic Hierarchy Process (FAHP)," International Journal Of Applied Mathematics And Informatics, vol. 1, no. 6, pp. 57-65, 2012.

[11] Do Q. H., Chen, J. F., "Prioritizing the Factor Weights Affecting Tourism Performance by FAHP," International Journal of Engineering Business Management, vol. 5, no. 1, pp. pp. 1-10, 2013, doi: 10.5772/57141. 
[12] Istianto Y, Sugiantoro B., "Design Of Decision Support System Selection Of Beach Tourism Object In Gunungkidul Using Fuzzy AHP Method," International Journal on Informatics for Development, vol. 6, no. 2, pp. 14-19, 2017, doi: 10.14421/ijid.2017.06203.

[13] Ramadiani R., Ramadhani B., Arifin Z., Jundillah M. L., Azainil A., "Decision support system for determining chili land using weighted product method," Bulletin of Electrical Engineering and Informatics (BEEI), vol. 9, no. 3, pp. 1229-1237, 2020, doi: 10.11591/eei.v9i3.2004.

[14] Overbeek M. V., Naatonis R. N., "Sistem Rekomendasi Destinasi Wisata Di Kota Kupang Dengan Metode Weighted Product," Jurnal HOAQ-Teknologi Informasi, vol. 10, no. 1 pp. 899-958, 2019.

[15] Anshori Y., "Pendekatan Triangular Fuzzy Number Dalam Metode Analytic Hierarchy Process," Jurnal Ilmiah Foristek, vol. 2, no. 1, pp. 126-135, 2012.

[16] Vinogradova-Zinkevič I., Podvezko V., Zavadskas E. K., "Comparative Assessment of the Stability of AHP and FAHP Methods," Symmetry, vol. 13, no. 3, p. 479, 2021, doi: 10.3390/sym13030479.

[17] Alyamani R., Long S., "The Application of Fuzzy Analytic Hierarchy Process in Sustainable Project Selection," Sustainability, vol. 12, no. 20, p. 8314, 2020, doi: 10.3390/su12208314.

[18] Lespier L. P., Long, S., Shoberg T., Corns S., "A model for the evaluation of environmental impact indicators for a sustainable maritime transportation systems," Frontiers of Engineering Management, vol. 6, no. 7, pp. 368-383, 2019, doi: 10.1007/s42524-019-0004-9.

[19] Zadeh, L. A., "Fuzzy Sets," Information and Control, vol. 8, no. 3, pp. 338-353, 1965, doi: 10.1016/S00199958(65)90241-X.

[20] Ertuğrul İ., Karakaşoğlu N., "Performance evaluation of Turkish cement firms with fuzzy analytic hierarchy process and TOPSIS methods," Expert Systems with Applications, vol. 36, no. 1, pp. 702-715, 2009, doi: 10.1016/j.eswa.2007.10.014.

[21] Ballı S., Korukoğlu S., "Operating System Selection Using Fuzzy AHP and TOPSIS Methods," Mathematical and Computational Applications, vol. 14, no. 2, pp. 119-130, 2009, doi: 10.3390/mca14020119.

[22] Çebi A., Karal H., "An application of fuzzy analytic hierarchy process (FAHP) for evaluating students' projects," Educational Research and Reviews, vol. 12, no. 3, pp. 120-132, 2017, doi: 10.5897/ERR2016.3065.

[23] Hsu T. K., Tsai Y. F., Wu H. H., "The preference analysis for tourist choice of destination: A case study of Taiwan," Tourism Management, vol. 30, no. 2, pp. 288-297, 2013, doi: 10.1016/j.tourman.2008.07.011.

[24] Saaty T. L., "Decision Making With The Analytic Hierarchy Process," International Journal of Services Sciences, vol. 1, no. 1, pp. 83-98, 2018, doi: 10.1504/IJSSCI.2008.017590

[25] Yap J. Y., Ho C. C., Ting C. Y., "Analytic Hierarchy Process (AHP) for business site selection," AIP Conference Proceedings, vol. 2016, no. 1, p. 020151, 2018, doi: 10.1063/1.5055553.

[26] Chang D. Y., "Application of the Extent Analysis Method on Fuzzy AHP," European Journal of Operational Research, vol. 95, no. 3, pp. 649-655, 1996, doi: 10.1016/0377-2217(95)00300-2.

[27] Mao L., Qi D. Y., A "Hybrid Methodology for Performance Assessment of Campus Network," Bulletin of Electrical Engineering and Informatics (BEEI), vol. 4, no. 4, pp. 334-344, 2015, doi: 10.11591/EEI.V4I4.547.

\section{BIOGRAPHIES OF AUTHORS}

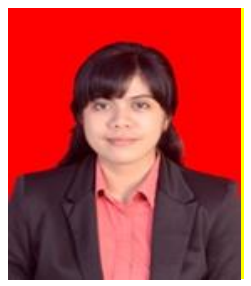

Christa Bire received her S.T from Atma Jaya University Yogyakarta (2011). She received her M.T also from Atma Jaya University Yogyakarta (2013). Her research interests are in information systems and artificial intelligence.

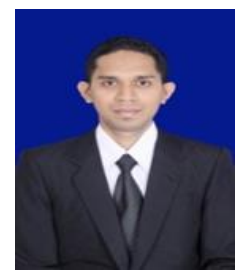

Daniel Kasse received his S.Kom from STIKOM Uyelindo Kupang (2010) and received his M.Eng from Gajah Mada University (2015). His research interest is in human computer interaction.

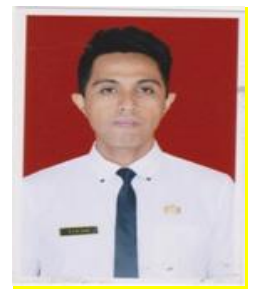

Rio Bire received his S.T from Atma Jaya University Yogyakarta (2010), received his M.B.A from Gajah Mada University (2012), and M.S.C.M from Massey University (2017). His research interests are in tourism and operations management. 